\title{
Phytotherapy Perspectives for Treating Fungal Infections, Migraine, Sebhorreic Dermatitis and Hyperpigmentations with the Plants of the Centaureinae Subtribe (Asteraceae)
}

\author{
Joanna Nawrot $($, Justyna Gornowicz-Porowska $₫$ and Gerard Nowak *(1) \\ Department and Division of Practical Cosmetology and Skin Diseases Prophylaxis, \\ Poznan University of Medical Sciences, 33 Mazowiecka Street, 60-623 Poznań, Poland; \\ joannac@ump.edu.pl (J.N.); justynagornowicz1@poczta.onet.pl (J.G.-P.) \\ * Correspondence: gnowak@ump.edu.pl; Tel./Fax: +48-61-8470628 \\ Academic Editor: Michal Tomczyk
}

Received: 28 September 2020; Accepted: 13 November 2020; Published: 15 November 2020

check for updates

\begin{abstract}
Sesquiterpene lactones, coumarins, phytoecdysones and phenolic compounds are characteristic of the species from the subtribe Centaureinae (Asteraceae). Many of the compounds isolated from plants of the Centaureinae subtribe have strong pharmacological properties. It may be suggested that these compounds' chemical structure might be an indicator of these pharmacological properties. The aim of the study was to describe recent studies in the field of phytotherapy, focusing on compounds isolated from chosen plants of Centaureinae and the possibilities of using them to treat antifungal infections, inhibit serotonin and ease symptoms of seborrhea dermatitis and hyperpigmentation. The results of these biological studies have shown that in the future, extracts from the above-mentioned plant material may be used as active substances in new safe and effective drugs.
\end{abstract}

Keywords: Asteraceae; sesquiterpene lactones; coumarins; phytoecdysones; arbutin; phytotherapy

\section{Introduction}

For a long time, pharmacologists have been analyzing natural compounds, such as sesquiterpene lactones, coumarins, phytoecdysones and phenol glucosides, isolated from the plants of the Asteraceae family.

Special interest has been given to sesquiterpene lactones because of their strong pharmacological properties [1]. Sesquiterpene lactones isolated from Matricariae flos, Arnicae flos and Millefoli herba have anti-inflammatory effects [2]. It has been established that sesquiterpene lactones can inhibit DTH (Delayed-Type Hypersensitivity test), especially contact dermatitis induced by intratracheal administration of hapten [3].

Coumarin compounds isolated from Centaureinae plants may be treated as chemotaxonomy markers for the Psephellus genus [4]. 7-hydroxycoumarin (umbelliferone) can absorb UV light in the range of 280-315 nm, and it is therefore used for anti-UV cosmetics production [5], and it is one of the active substances appearing in the root and herb of Hieracium pilosella L., a plant with proven antifungal properties [6].

Phytoecdysones are yet another group of compounds appearing in the species of the mentioned subtribe [7], and plants from the Serratula genus are their most efficient source [8]. Reliable qualitative and quantitative analyses of phytoecdysteroids isolated from plants are important for the development of new pharmaceutical products [9]. Natural steroids are nowadays often chosen for skin change treatment, replacing synthetic steroids [10]. 
Phenol glucoside arbutin usually appears in plant extracts along with methyl arbutin and hydroquinone. The first of these two compounds weakens arbutin effectiveness, while hydroquinone's safety is sometimes questioned [11].

Phytochemistry of plants from the Asteraceae family has been analyzed in the Department of Medicinal and Cosmetic Natural Products of Poznan University of Medical Sciences (now Department and Division of Practical Cosmetology and Skin Diseases Prophylaxis) for over forty years. We have narrowed down our research to the Centaureinae subtribe and managed to analyse such species as Zoegea baldschuanica C. Winkl., Z. leptaurea L, Centaurea sp., Chartolepis sp., Rhaponticum sp., Leuzea sp., Psephellus bellus (Trautv.) Wagenitz, P. sibirica (L.) Wagenitz, Stizolophus balsamita (Lam.) K. Koch, Serratula coronata L., S. quinquefolia M. Bieb. ex Willd. (Figure S1) and others.

From the aerial parts of the above-mentioned plants, sesquiterpene lactones, coumarins, phytoecdysones and phenol compounds have been isolated. The isolation of the active compounds was conducted based on the procedures specified for the sesquiterpene lactones [12], phytoecdysones [8], coumarins [13] and phenolic glycosides [14].

Isolated compounds were identified by NMR spectra. They were run on a Bruker Avance 600 instrument using 600 and $150 \mathrm{MHz}$ frequencies for hydrogen nuclei $\left({ }^{1} \mathrm{H}\right)$ and carbon nuclei $\left({ }^{13} \mathrm{C}\right)$, respectively, and tetramethylsilane (TMS) was used as an internal standard. The spectra were obtained for $\mathrm{CDCl}_{3}$ or DMSO- $d_{6}$ solutions at $298 \mathrm{~K}$. Chemical shifts are given in ppm, and coupling constants $J$ are given in Hz (Tables S1-S3; Figure S2) [15,16]. Absolute configuration of the dominant compound from the S. quinquefolia leaf was based on the crystallography method (Figure S3) [17].

In our studies, over twenty new compounds were isolated and identified. For the last ten years, the focus of our study has been on pharmacological properties of isolated compounds and the possibilities of creating new drugs with the extracts from Centaureinae plants as active substances. Table 1 shows the pharmacological properties of selected extracts and compounds from some plants of the Centaureinae subtribe.

As mentioned above, compounds from Centaureinae plants have differentiated pharmacological properties, which is why it is very important to choose the appropriate biological study for specific compounds or plant extracts. Therefore, the chemical structure of compounds was also carefully analyzed, making it possible to establish a correlation between compounds' chemical structure and their biological properties.

Based on previous studies and on compounds' chemical structure, we have decided to test the compounds and plant extracts in treating antifungal infections, seborrheic dermatitis and hyperpigmentation. We have also conducted tests for serotonin inhibition properties, which may help in finding new ways of treating migraines.

The aim of this review was to describe recent studies in the field of phytotherapy and present the results concerning the pharmacological properties of compounds from plants of the Centaureinae subtribe, which may help in future treatment of antifungal infections, migraine, seborrheic dermatitis and hyperpigmentations. 
Table 1. Pharmacological properties of the compounds and the extracts from selected plants of Centaureinae subtribe.

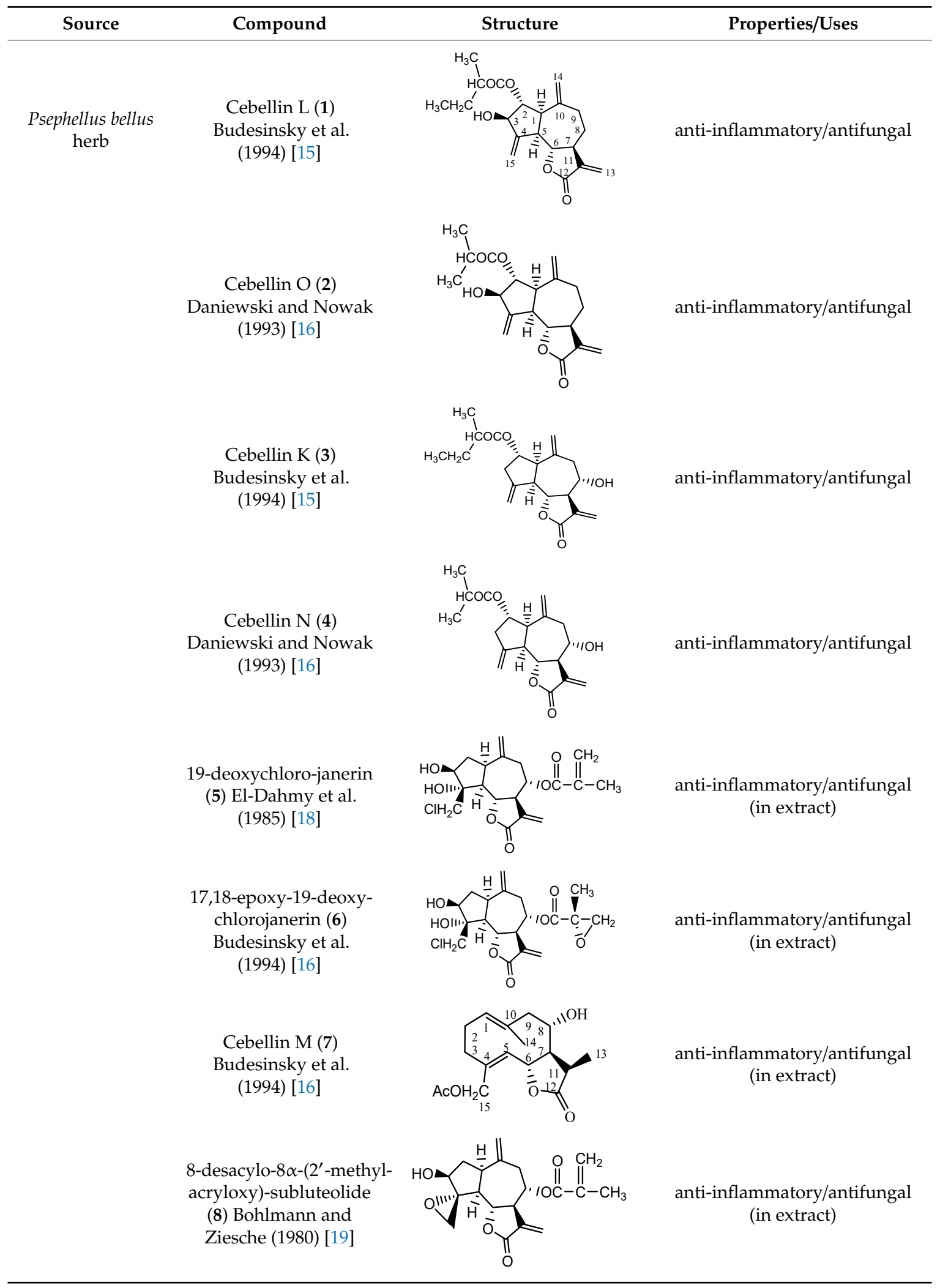


Table 1. Cont.

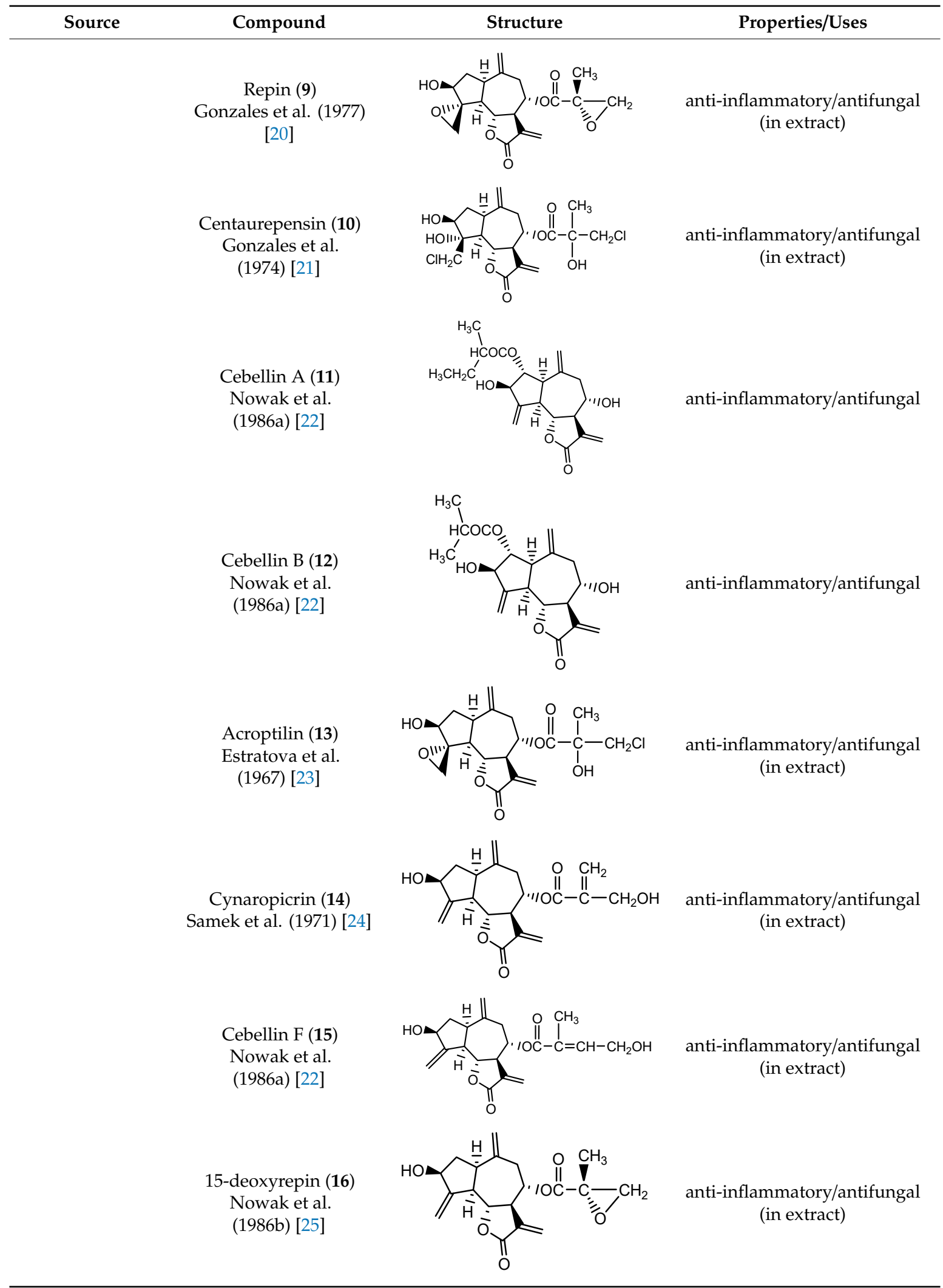


Table 1. Cont.

\begin{tabular}{|c|c|c|c|}
\hline Source & Compound & Structure & Properties/Uses \\
\hline & $\begin{array}{l}\text { Chlorojanerin (17) } \\
\text { Stevens (1982) [26] }\end{array}$ & & $\begin{array}{l}\text { anti-inflammatory/antifungal } \\
\text { (in extract) }\end{array}$ \\
\hline & $\begin{array}{c}\text { 8-desacetyl- } \\
\text { centaurepensin-8-O- } \\
\left(4^{\prime} \text {-hydroxy)-tiglate }\right. \\
\text { (18) Stevens (1982) [26] }\end{array}$ & & $\begin{array}{l}\text { anti-inflammatory/antifungal } \\
\text { (in extract) }\end{array}$ \\
\hline & $\begin{array}{l}\text { Repensolide (19) } \\
\text { Jakupovic et al. } \\
\quad \text { (1986) [27] }\end{array}$ & & $\begin{array}{l}\text { anti-inflammatory/antifungal } \\
\text { (in extract) }\end{array}$ \\
\hline & $\begin{array}{l}\text { Janerin (20) } \\
\text { Gonzales et al. } \\
\text { (1977) [20] }\end{array}$ & & $\begin{array}{l}\text { anti-inflamatory/antifungal } \\
\text { (in extract) }\end{array}$ \\
\hline & $\begin{array}{c}\text { 8-4'tiglinate-8- } \\
\text { desacetyl-subluteolide } \\
\text { (21) Budesinsky et al. } \\
\text { (1994) [16] }\end{array}$ & & $\begin{array}{l}\text { anti-inflamatory/antifungal } \\
\text { (in extract) }\end{array}$ \\
\hline & $\begin{array}{l}\text { Cebellin G (22) } \\
\text { Nowak et al. } \\
\text { (1986a) [22] }\end{array}$ & & $\begin{array}{l}\text { anti-inflamatory/antifungal } \\
\text { (in extract) }\end{array}$ \\
\hline & $\begin{array}{l}\text { Cebellin H (23) } \\
\text { Nowak et al. } \\
\text { (1986a) [22] }\end{array}$ & & $\begin{array}{l}\text { anti-inflamatory/antifungal } \\
\text { (in extract) }\end{array}$ \\
\hline & $\begin{array}{l}\text { Cebellin I (24) } \\
\text { Nowak et al. } \\
\text { (1986a) [22] }\end{array}$ & & $\begin{array}{l}\text { anti-inflammatory/antifungal } \\
\text { (in extract) }\end{array}$ \\
\hline & $\begin{array}{l}\text { Repdiolide (25) } \\
\text { Bohlmann et al. } \\
\quad(1982)[28]\end{array}$ & & $\begin{array}{l}\text { anti-inflammatory/antifungal } \\
\text { (in extract) }\end{array}$ \\
\hline
\end{tabular}


Table 1. Cont.

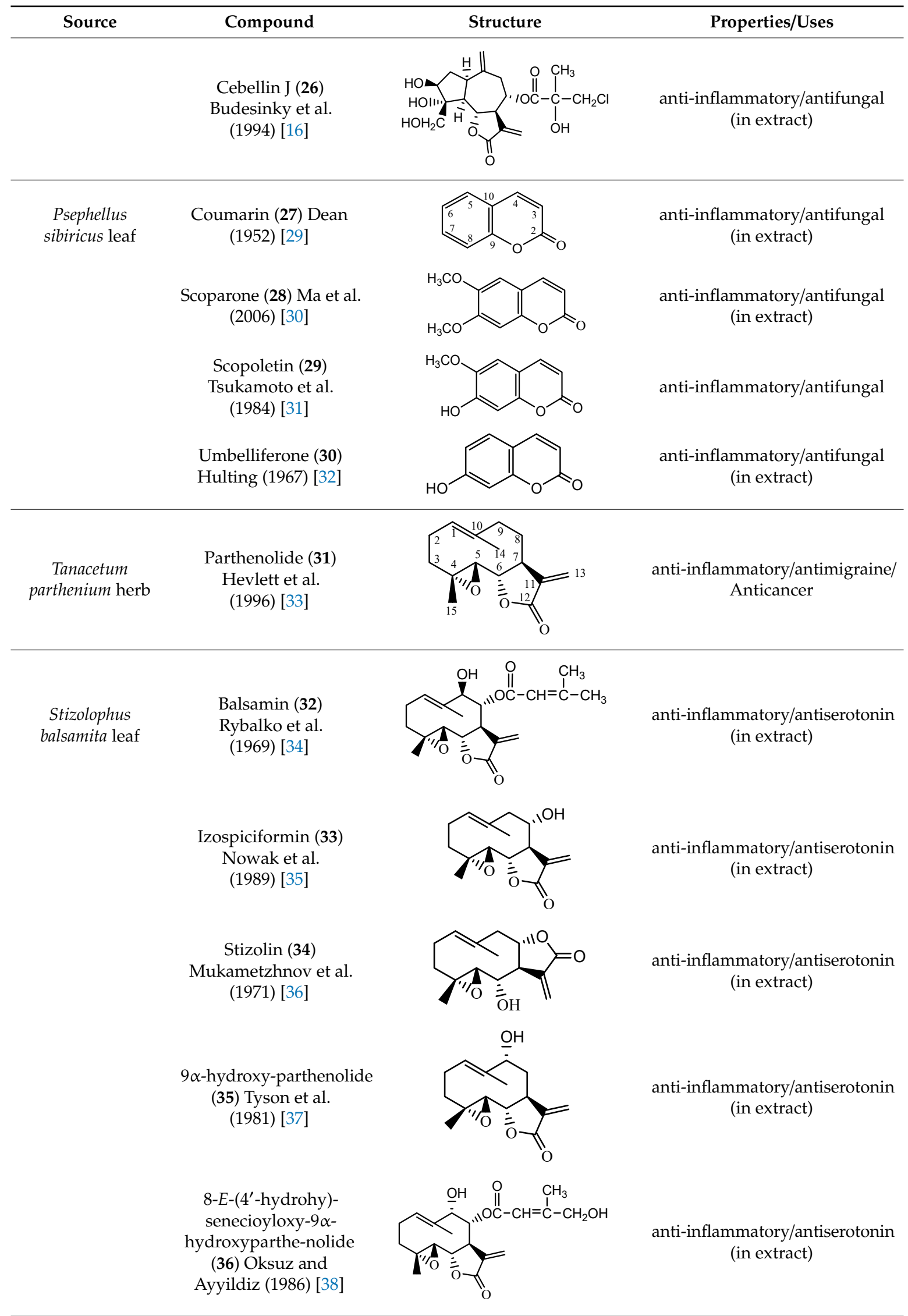


Table 1. Cont.

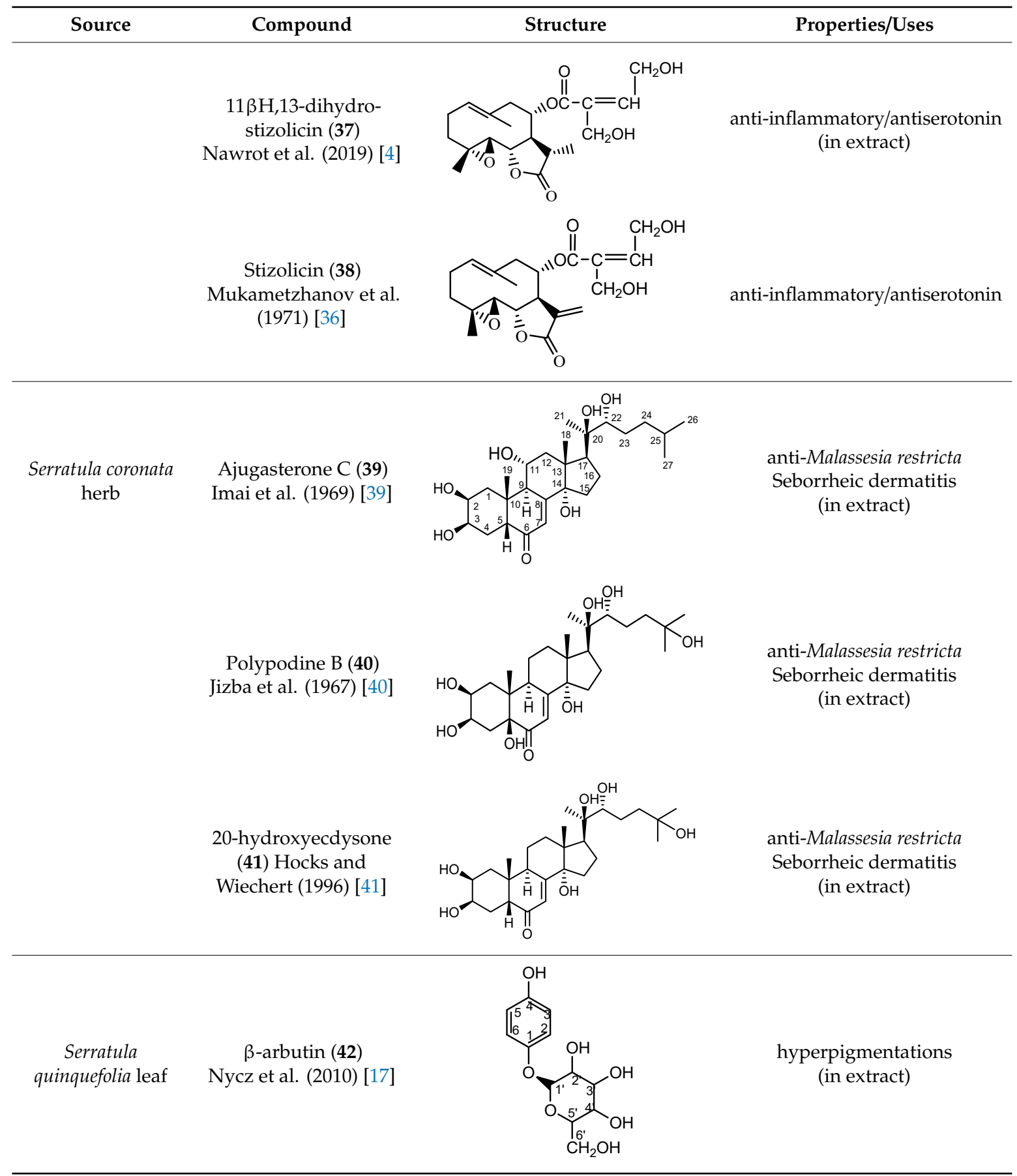

\section{Selected Centaureinae (Asteraceae) Plant Materials in Phytotherapy}

\subsection{Phytotherapy Possibilities for Treating Fungal Infections}

Fungal infections affect about $40 \%$ of the world's population and may be viewed as an epidemiological, therapeutic and social problem. Over a billion people are directly affected by mycoses globally, 150 million of whom have a serious or life-threatening infection [42]. Fungal infections can cause serious illnesses, several of which may be fatal if left untreated. Commonly used antibiotics change human microflora and consequently increase the number of people with impaired immunity [43].

Such factors as the development of industry, agriculture, technology and life extension make the population more susceptible to infections [44]. The number and variety of fungi causing infections 
are increasing all over the world. Not only in different parts of the world but sometimes even within one country, there are differences in fungal flora, and species of fungi can be identified with variable frequency of occurrence. Among most commonly occurring fungi infections are aspergillosis, coccidioidomycosis, candidosis, cryptococcosis, mycetomas, histoplasmosis, mucormycosis, and paracoccidio-idomycosis [45].

Conventional antifungal treatment is based on polyene agents, flucitosine and azole agents, or more recently, on virulence factor inhibitors and immunomodulators. This has led to the production of new and improved azoles and polyene formulations, as well as a new family of drugs, the echinocandins [46].

Some germacranolides isolated from Centaurea species showed antifungal activity against Cunninghamella echinulate. The authors who found this concluded that a relatively low polarity is one of the molecular requirements for the antifungal activity of sesquiterpene lactones [47].

Coumarins are compounds with lactone structure that also show antifungal activity. Some coumarin derivatives were tested against the fungal strains Candida albicans (ATCC 14053), Aspergillus fumigatus (ATCC 16913) and Fusarium solani (ATCC 36031) using the broth microdilution method and showed strong antifungal activity [48]. Coumarins also exhibit anti-inflammatory activity [49].

Furthermore, $0.39 \%$ guaianolides $1,11,12,13$; the mixture of guaianolides 1-4; a coumarin compound 29 and dry methanol extracts from P. bellus herb with 26 sesquiterpene lactones (compounds 1-26); and P. sibiricus leaf with four coumarins (compounds 27-30) (Table 1) were used for an antifungal study against following clinical strains of fungi: Candida albicans, C. famata, C. glabrata, C. parapsilosis, Rhodotorula rubra, Trichophyton rubrum, T. mentagrophytes var. interdigitale, Microsporum canis and Scopulariopsis brevicaulis.

Pathogenic fungi were collected from the patients with fungal infection diagnosed by a dermatologist. The patients were not treated with any other antifungal drugs.

Clinical strains of fungi were suspended in $0.9 \% \mathrm{NaCl}$ solution and adjusted to the desired concentration of 1 in McFarland standard. The suspension was transferred to the sterile paper discs and placed in the Petri dishes. After drying for about $15 \mathrm{~min}$, the surface was spread with $10 \mu \mathrm{g}$ of the studied substance dissolved in dimethylsulfoxide (DMSO) (concentration 0.39\%). After $15 \mathrm{~min}$, the Petri dishes were incubated. Candida cultures were incubated for $72 \mathrm{~h}$ at $36^{\circ} \mathrm{C}$. Dermatophytes (Trichophyton sp., Rhodotorula sp., Microsporum sp.) and mold fungus (Scopulariopsis brevicaulis) were incubated at $27^{\circ} \mathrm{C}$ for two weeks (Figure S4).

The inhibition zones' diameter (in $\mathrm{mm}$ ) was measured, and thus the antifungal properties of the studied substances were assessed. Fungal growth analysis was performed under a stereomicroscope (Nikon SMZ800, Tokyo, Japan) at the Microbiology Section (Department of Dermatology, Poznan University of Medical Sciences, Poznan, Poland).

The analysis of all fungi cultures suitable for assessment showed that all of the studied compounds have antifungal properties (Table 2). Due to some compounds' limited amounts, only $0.39 \%$ solutions of the compounds and extracts were used during the study.

The diameters of the inhibition zones were measured to assess how susceptible the fungi are to the activity of the analyzed compounds. The analyzed fungi could be classified into the following categories:

Very Susceptible, with the diameter of inhibition zone $20 \mathrm{~mm}$ or over $20 \mathrm{~mm}$ Susceptible: with the diameter of inhibition zone between $10 \mathrm{~mm}$ and $19 \mathrm{~mm}$ Moderately susceptible: with the diameter of inhibition zone between $1 \mathrm{~mm}$ and $9 \mathrm{~mm}$ Resistant: no inhibition zone 
Table 2. The assessment of fungi susceptibility to studied natural compounds.

\begin{tabular}{|c|c|c|c|c|c|c|c|c|c|}
\hline $\begin{array}{l}\text { Herbal } \\
\text { Substance }\end{array}$ & $\begin{array}{l}\text { Candida } \\
\text { albicans }\end{array}$ & $\begin{array}{l}\text { Candida } \\
\text { famata }\end{array}$ & $\begin{array}{l}\text { Candida } \\
\text { glabrata }\end{array}$ & $\begin{array}{l}\text { Candida } \\
\text { parapsilosis }\end{array}$ & $\begin{array}{l}\text { Rhodotorula } \\
\text { rubra }\end{array}$ & $\begin{array}{l}\text { Trichophyton } \\
\text { rubrum }\end{array}$ & $\begin{array}{c}\text { Trichophyton } \\
\text { mentagrophytes } \\
\text { var. } \\
\text { interdigitale }\end{array}$ & $\begin{array}{l}\text { Microsporum } \\
\text { canis }\end{array}$ & $\begin{array}{c}\text { Scopulariopsis } \\
\text { brevicaulis }\end{array}$ \\
\hline Cebellin L & - & $\mathrm{S}$ & $\mathrm{S}$ & VS & S & $\mathrm{S}$ & VS & - & $\mathrm{S}$ \\
\hline Cebellins & S & - & VS & - & VS & - & VS & VS & MS \\
\hline Cebellin A & M & - & S & - & S & - & S & - & VS \\
\hline Cebellin B & - & $\mathrm{s}$ & $\mathrm{s}$ & MS & - & $\mathrm{s}$ & $\mathrm{S}$ & - & MS \\
\hline Acroptilin & - & MS & - & - & - & VS & MS & - & - \\
\hline Scopoletin & - & $\mathrm{S}$ & S & MS & - & $\mathrm{S}$ & MS & - & MS \\
\hline $\begin{array}{l}\text { P. bellus } \\
\text { extract }\end{array}$ & - & S & S & S & - & VS & VS & - & - \\
\hline $\begin{array}{l}\text { P. sibiricus } \\
\text { extract }\end{array}$ & - & S & - & S & - & - & S & - & - \\
\hline
\end{tabular}

The measurements were taken for three days from Candida cultures and 14 days from the dermatophytes and mold fungus (Scopulariopsis brevicaulis). The assessment of compounds' antifungal activity on Candida albicans was only possible in the case of cebellins 2-4 mixture and cebellin A (11) due to the difficulties with growing these fungi strain cultures. Other strains turned out to be easier to grow, which is why the antifungal activity of all of the studied compounds could have been observed [50].

The most significant number of fungi (among them Candida albicans, Microsporum canis and Rhodotorula rubra) strains turned out to be very susceptible to cebellins 1-4 from the P. bellus herb (Figure 1). These compounds are the most lipophilic of the studied lactones. [47].

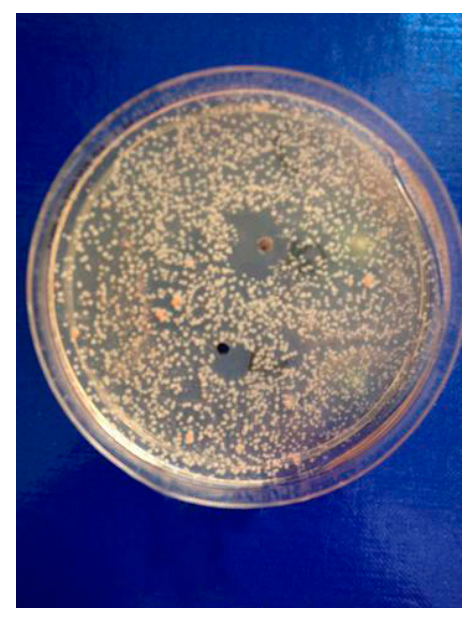

Figure 1. The results of susceptibility assessment of Rhodotorula rubra to the mixture of C-2 ester guaianolides (compound $\mathbf{1}$ inhibition zone diameter $=12$, compounds $\mathbf{2}-\mathbf{4}$ inhibition zone diameter $=22 \mathrm{~mm}$ ).

Yeast-like fungi Candida famata and C. glabrata, as well as dermatophytes from the Trichophyton genus, T. rubrum and T. mentagrophytes var. interdigitale, were the most susceptible to the analyzed compounds. The highest potency of the P. bellus herb extract was shown (inhibition zone's diameter reached $34 \mathrm{~mm}$ ) [50].

It may be suggested that low-polar sesquiterpene lactones (compounds 1-13), mostly those with an ester on C2 (compounds 1-4, 11, 12) are responsible for such a strong antifungal effect of the extract from the P. bellus herb.

Scopoletin (29) (yielded in yellow crystals-Figure S2) also showed antifungal properties, and the strains Candida famata, C. glabrata and Trichophyton rubrum were susceptible to it. On the other hand, T. mentagrophytes var. interdigitale and Scopulariopsis brevicaulis turned out to be only moderately susceptible to this compound. 
Six guaianolides isolated from the $P$. bellus herb $(\mathbf{1}-\mathbf{4}, \mathbf{1 1}, \mathbf{1 2})$ have an additional ester on C2. Its structure (methyl groups) and location might be related to the compound's lipophilicity. The compounds with the additional ester have higher $\mathrm{R}_{\mathrm{f}}$ value in a nonpolar mobile phase, which can be interpreted as a lipophilicity indicator (Figure S5). Further research is needed to establish whether there is a correlation between the presence of this particular ester in the compounds' chemical structure and their lipophilicity, which suggests the compounds' ability to penetrate through the fungal cell wall and consequently destroying it [47].

In the chemical structure of each of the isolated coumarins from the leaves of P. sibiricus, a lactone ring can be observed. As the lactones have proven anti-microbial properties, this element of the structure was a reason for choosing these compounds for biological studies. The second reason was the coumarins' lipophilicity, as shown on the chromatogram (Figure $S 6$ ). The coumarins have a high $R_{f}$ value in a nonpolar mobile phase.

\subsection{Possibilities for Phytotherapy in Serotonin Inhibition}

Chronic migraine headaches are an important health problem. A headache in a migraine episode is described as hemicranial, pulsating and so intense that it strongly interferes with the patient's everyday life [51]. One explanation of the origin of migraines is the "serotonin theory", confirmed by the increased excretion of serotonin metabolites in urine during the headache episode. Serotonin (5-HT) is released from platelets, which causes contraction of the smooth muscle of the blood vessels [52]. Afterward, as a result of biochemical changes, the serotonin level decreases, causing vasodilation and an increase in vascular permeability, allowing the flow of substances able to lower the sensitivity threshold of perivascular space nociceptor [53].

Parthenolide (31) is a sesquiterpene lactone derived from the leaves of Feverfew (Tanacetum parthenium) and is considered the main bioactive component of this herb [54]. Feverfew is used orally or as an infusion for the treatment of migraine, arthritis, fever and stomachache [55]. Parthenolide (31) reduces the cellular level of GSH in cancer cells, followed by ROS accumulation and apoptosis [56]. Parthenolide's ability to induce cell death, mainly in cancer cells, while sparing healthy cells is unique and may be linked to the presence of 4,5-epoxide, lactone ring and an exo-methylene [57]. The compound also protects normal cells from UVB and oxidative stress, and it seems to have the potential to target some cancer stem cells [58].

The serotonin inhibition ex vivo study covered germacranolides 33, 34, 38 and 2\% extract from the St. balsamita leaf with seven parthenolide (31) derivatives (compounds 32-38). During the study, it was proven that izospiciformin (33), stizolin (34) and stizolicin (38), as well as the extract with four additional germacranolides $(32,35-37)$, inhibit the release of 5-HT from platelets more effectively than parthenolide (31), and the results were statistically significant: $(31 p=0.0477 ; 33 p=0.0001 ; 34$ $p=0.0380 ; 38 p=0.0389$; methanol extract from St. balsamita leaf $p=0.0097$ ) [59]. Izospiciformin (33) and the ethanol extract from the St. balsamita leaf showed the most potent effect.

Two elements may be found in the chemical structures of the guaianolides isolated from P. bellus herb as well as in germacranolides isolated from the St. balsamita leaf. A lactone ring coupled with an exo-methylene enables inhibition of the cellular enzymes through Michael nucleophilic addition [60]. In consequence, these compounds exhibit antiviral activity, including that of the SARS-CoV-2 virus [61], as well as antiprotozoal [62] and antiserotonin activity, the latter being responsible for lactones' antimigraine effect [63].

In St. balsamita leaf, there are seven parthenolide derivatives (32-38), all of which contain 4,5-epoxide. The difference in the chemical structure between the parthenolide (31) and its derivatives from St. balsamita should be stressed. Compounds 32-38, along with the three above-mentioned elements characteristic for a parthenolide (4,5-epoxide, lactone ring and an exo-methylene), have an additional element, namely a substituent on C-8, which significantly increases the potency of the antiserotonin effect compared to parthenolide [59]. 


\subsection{Phytotherapy's Possibilities in Treating Seborrheic Dermatitis}

The bothersome symptoms of seborrheic dermatitis (SD) are difficult to control. SD is a chronic dermatitis characterized by erythema and skin flaking, which occur most often on the face, scalp, ears, chest and body folds-in other words, places with a high concentration of sebaceous glands [64].

20-hydroxyecdysone derivatives found in plants of the Serratula genus, when applied to the skin, restore dermis and strengthen protective functions of the epidermis, making the skin more hydrated and resilient. Phytoecdysones may therefore be used in dry and very dry skin care and eases such symptoms as ichtyosis and psoriatic conditions [65]. Phytoecdysones are able to activate keratinocytes and increase their amount and differentiation, which is why those compounds are used in projects of creating artificial skin [66].

It is postulated that phytoecdysones may have a significant impact on the reduction of inflammation, probably through their immunomodulatory function and the modulation of proinflammatory cytokines level (e.g., IL-6, TNF- $\alpha$ ) [67]. Moreover, it has been reported that phytoecdysteroids improve skin quality by accelerating the healing process of wounds and burns [68]. Several studies [69] have claimed associations between Malassezia restricta lipase and seborrheic dermatitis. In light of this, ecdysteroids, especially 20-hydroxyecdysone (41), probably enhance antifungal immunity, resulting in the reduction of disease symptoms [70].

Ecdysteroids from plants of the Centaureinae subtribe are characterized by two $\mathrm{OH}$ groups on $\mathrm{C} 2$ and C3. Some, though only those of vegetable origin, have extra hydroxyl groups on C1, C5 and C11 (Table 1). The presence of those additional groups seems to translate into increased safety in use [71].

S. coronata herb is the source of phytoecdysones [58], which were studied for their use in easing the symptoms of seborrheic dermatitis. Dry ethanol extract from $S$. coronata herb standardized in its content of three dominating phytoecdysones-ajugasterone C (39), polypodine B (40) and 20-hydroxyecdysone (41) - was used as an active substance in preparing the cream. The amphiphilic cream base was chosen specifically for its ability to easily release the active substance (Lekobaza Pharma Cosmetic, Fargon, Poland). The base was mixed with water extract containing $22.39 \%$ ecdysones to achieve a $2.5 \%$ concentration of the active substance in the cream. Each patient was treated with $8 \mathrm{mg}(=1.8 \mathrm{mg}$ of the active substance) of the cream, which was applied, directly to the changed skin, two times a week for six weeks [59].

The cream with phytoecdysones (compounds 39-41) proved to be an effective and safe preparation for treating skin changes caused by seborrheic dermatitis [59].

\subsection{Phytotherapy's Possibilities in Treating Skin Discoloration}

Skin hyperpigmentation is a common cause of patients' visits to beauty shops and dermatological clinics. Usually located on the exposed parts of the body (face, neck, neckline, forearms and backs of the hands), these changes may be the result of inflammation, endocrine disorders and systemic diseases, as well as UV radiation, phototoxic or photoallergic substances contained in medicines, herbs and cosmetics. They occur due to the disturbance of melanin synthesis and abnormal distribution of melanin in the skin [72].

Lighter skin tones have long been associated with youth and beauty among a variety of Asian cultures. Investment in skin-whitening agents, boosted by markets in Asian countries, especially those in China, India and Japan, is increasing annually. Skin color is influenced by a number of intrinsic factors, including skin types and genetic background, and extrinsic factors, including the degree of sunlight exposure and environmental pollution [73].

Cosmeceuticals are commonly used for hyperpigmentation. These disorders are generally difficult to treat, hence the need for skin-lightening agents. Arbutin in cream is used as a first choice in treating hyperpigmentation [74].

$\beta$-arbutin, phenol glucoside, is a compound with anti-inflammatory effect. Moreover, its mechanism of action is based on inhibiting the activity of tyrosinase, a vital enzyme in the process of melanin synthesis [75]. As it was possible to isolate an unexpectedly large quantity of $\beta$-arbutin 
(42) from St. quinquefolia plant material without methylarbutin and hydroquinone (Figure S7) [14], water extract from the leaves of $S$. quinquefolia was used for biological studies. The extract was tested during the clinical trial for their efficiency in skin discoloration, specifically melasma and lentigo solaris treatment. A cream containing $2.51 \%$ of active compound was applied to the discolored place twice a day -in the morning and the evening (one application of $100 \mathrm{mg}=2.5 \mathrm{mg}$ of the active substance)-for eight weeks [76].

The cream with this extract decreased melanin level in the skin pigmentation spots. The clinical effect, in the form of lightening and evening skin tone on the discolored side, was observed in $75.86 \%$ of the female patients with melasma and $56.00 \%$ of the female patients with lentigo solaris. The cream with the aqueous extract from the leaf of five-leaf Serratula proved to be an effective and safe preparation for lightening skin discoloration $(66.67 \%$ of the female patients in the study group) [76].

\section{Conclusions}

Recent studies show that searching for new possibilities of phytotherapy using compounds isolated from Centaureinae plants is worth the effort. Treatment based on active substances from plants of the Centaureinae subtribe is often effective and does not cause side effects, as was demonstrated on an example of antifungal infections and SD and melasma and lentigo solaris treatment.

There seem to be a correlation between the chemical structure of compounds and their pharmacological properties, which may be helpful, e.g., in selecting the right biological studies for specific compounds. Further research is needed on this issue.

Supplementary Materials: The Supplementary Materials are available online-Figure S1: Plants in the Garden of Medicinal Plants in the Department and Division of Practical Cosmetology and Skin Diseases Prophylaxis, Poznan University of Medicinal Sciences; Table S1: ${ }^{1} \mathrm{H}$ NMR $(600 \mathrm{MHz})$ spectroscopic data $\left(\delta_{\mathrm{H}}\right.$ in ppm, mult; $J$ in $\mathrm{Hz})$ of compounds: 1, 11-13; Table S2: ${ }^{1} \mathrm{H}$ NMR $(600 \mathrm{MHz})$ spectroscopic data $\left(\delta_{\mathrm{H}}\right.$ in ppm, mult; $J$ in $\left.\mathrm{Hz}\right)$ of: izospiciformin (33), stizolin (34), and stizolicin (38); Table S3: ${ }^{1} \mathrm{H}$ NMR data $(600,20 \mathrm{MHz})$ of ajugasterone C (39), polypodine B (40) and 20-hydroxyecdysone (41) (in $\mathrm{CD}_{3} \mathrm{OD}$ ); Figure S2: ${ }^{1} \mathrm{H}$ NMR spectroscopic data of compound 29 and crystals of scopoletin; Figure S3: X-ray analysis of $\beta$-arbutin from S. quinquefolia leaf and crystals of arbutin; Figure S4: Candida glabrata, Trichophyton rubrum, Microsporum canis, Scopulariopsis brevicaulis cultures; Figure S5: TLC of compounds from Psephellus bellus herb; Figure S6: TLC of coumarins from Psephellus sibiricus leaf; Figure S7: The HPLC chromatogram of the water extract from the S. quinquefolia leaf.

Author Contributions: J.N., J.G.-P. and G.N. conceived and initiated described projects, analysed data and supervised the project. All authors have read and agreed to the published version of the manuscript.

Funding: The research received no external funding.

Conflicts of Interest: The authors declare no conflict of interest.

\section{References}

1. Bruno, M.; Bancheva, S.; Roselli, S.; Maggio, A. sesquiterpenoidsin subtribe Centaureinae (Cass) Dumort (tribe Cardueae, Asteraceae): Distribution, ${ }^{13} \mathrm{C}$ NMR spectra data and biological properties. Phytochemistry 2013, 95, 19-93. [CrossRef] [PubMed]

2. Lyß, G.; Glasl, S.; Jurenitsch, J.; Pahl, H.L.; Merfort, I. A sesquiterpene and sesquiterpene lactones from Achillea millefolium group possess anti-inflammatory properties but do not inhibit the transcription factor NF-k B. Pharm. Pharmacol. Lett. 2000, 10, 13-15.

3. Matsuda, K.; Kagerura, T.; Toguchida, I.; Ueda, H.; Morikawa, T.; Yoshikawa, M. Inhibitory Effects of Sesquiterpenes from Bay-lef on Nitric Oxide Production in Lipopolisaccharide-actived Macrophages: Structure Requirement and Role of Heat-shock Protein Induction. Life Sci. 2000, 66, 2151-2157. [CrossRef]

4. Nawrot, J.; Budzianowski, J.; Nowak, G. Phytochemical profiles of leaves of Stizolophus balsamita and Psephellus sibiricus and their chemotaxonomic implications. Phytochemistry 2019, 159, 172-178. [CrossRef] [PubMed] 
5. Malinowska, M.; Bielawska, K. Metabolism and antioxidant properties of coumarins. Bromat. Chem. Toksykol. 2013, 3, 393-403.

6. European Medicines Agency. 2015EMA/HMPC/680374/2013 Committee on Herbal Medicinal Products (HMPC) European Union Herbal Monograph on Hieracium pilosella L.; herba cum radice. 2015. Available online: https://www.ema.europa.eu/en/documents/herbal-monograph/final-european-unionherbal-monograph-hieracium-pilosella-1-herba-cum-radice_en.pdf (accessed on 9 November 2020).

7. Martins, L.; Hellwig, F.K. Systematic position of the genera Serratula and Klasea within Centaureinae (Cardueae, Asteraceae) inferred from ETS and ITS sequence data and new combinations in Klasea. Taxon 2005, 54, 632-638. [CrossRef]

8. Báthori, M.; Pongrácz, Z. Phytoecdysteroids-From isolation to their effects on humans. Curr. Med. Chem. 2005, 12, 153-172. [CrossRef]

9. Dinan, L. The Karlson lecture Phytoecdysteroids: What use are they? Arch. Insect. Biochem. Physiol. 2009, 72, 126-141. [CrossRef]

10. Hajar, T.; Leshem, Y.A.; Hanifin, J.M.; Nedorost, S.T.; Lio, P.A.; Paller, A.S.; Block, J.; Simpson, E.L. (The National Eczema Association Task Force). A systematic review of topical corticosteroid withdrawal ("steroid addiction") in patients with atopic dermatitis and other dermatoses. J. Am. Acad. Dermatol. 2015, 72, 541-549. [CrossRef]

11. Garcia de Arriba, S.; Naser, B.; Nolte, K.U. Risk assessment of free hydroquinone derived from Arctostaphylos uva-ursi folium herbal preparations. Int. J. Toxicol. 2013, 32, 442-453. [CrossRef]

12. Nowak, G.; Drozdz, B.; Holub, M. Sesquiterpene lactones of the Cardueae, subtribe Centaureinae. In Compositae: Systematics. Proceedings of the International Compositae Conference; Hind, D.J.N., Beentje, H.J., Eds.; Royal Botanic Gardens, Kew: Richmond, UK, 1994; Volume 1, pp. 219-227.

13. Jain, P.K.; Joshi, H. Coumarin: Chemical and pharmacological profile. J. Appl. Pharm. Sci. 2012, 2, $236-240$.

14. Morag, M.; Nowak, G.; Michalak, M. The leaves of Serratula quinquefolia M.B. as a new arbutin source. Post. Fitoter. 2013, 1, 17-21.

15. Budesinsky, M.; Nowak, G.; Rychlewska, U.; Hodgson, D.J.; Saman, D.; Daniewski, W.M.; Holub, M. Structure of sesquiterpene lactones of some species of subtribe Centaureinae. Collect. Czech. Chem. Commun. 1994, 59, 1175-1201. [CrossRef]

16. Daniewski, W.M.; Nowak, G. Further sesquiterpene lactones of Centaurea bella. Phytochemistry 1993, 32, 204-205. [CrossRef]

17. Nycz, E.J.; Małecki, G.J.; Morag, M.; Nowak, G.; Ponikiewski, L.; Switlicka, A.; Kusz, J. Arbutin: Isolation, X-ray structure and computional studies. J. Mol. Struct. 2010, 980, 13-17. [CrossRef]

18. El-Dahmy, S.; Bohlmann, F.; Sarg, T.M.; Ateya, A.; Farrag, N. New guaianolides from Centaurea aegyptica. Planta Med. 1985, 51, 176-177. [CrossRef]

19. Bohlmann, F.; Ziesche, J. Naturally occurring terpene derivatives. Part 253. New guaianolides and acetyleniccompounds from Ptilostemon species. Phytochemistry 1980, 19, 692-696. [CrossRef]

20. Gonzalez, A.G.; Bermejo, J.; Massanet, G.M. Aportacion al estudio quimiotaxonomico del genero Centaurea. Rev. Lat. Quim. 1977, 8, 176-181.

21. González, A.G.; Bermejo, J.L.J.; Bretón, J.L.; Massanet, G.M.; Triana, J. Chlorohyssopifolin C, D, E and vahlenin, four new sesquiterpene lactones from Centaurea hyssopifolia. Phytochemistry 1974, 13, $1193-1197$. [CrossRef]

22. Nowak, G.; Drozdz, B.; Holub, M.; Budesinsky, M.; Saman, D. Sesquiterpene lactones. XXXI. New guaianolides in Centaurea bella Trautv. and Centaurea adjarica Alb. Acta Soc. Bot. Pol. 1986, 55, 227-231. [CrossRef]

23. Estratova, R.J.; Rybalko, K.S.; Rzasade, R.Y. Acroptilin-A new sesquiterpene lactone from Acroptilon repens. Khim. Prir. Soed. 1967, 4, 284-286.

24. Samek, F.C.; Holub, M.; Drozdz, B.; Jomni, G.; Corbella, A.; Gariboldi, P. Sesquiterpene lactones of Cynara scolymus L. species. Tetrahedrom Lett. 1971, 50, 4775-4778. [CrossRef]

25. Nowak, G.; Drozdz, B.; Holub, M.; Lagodzinska, A. Sesquiterpene XXXIII. Guaianolides in the subgenus Psephellus (Cass.) Schmalh. genus Centaurea L. Acta Soc. Bot. Pol. 1986, 55, 629-637. [CrossRef]

26. Stevens, K.I. Sesquiterpene lactones from Centaurea repens. Phytochemistry 1982, 21, 1093-1098. [CrossRef]

27. Jakupovic, J.; Jia, Y.; Pathak, V.P.; King, R.M. Bisabolone derivatives and sesquiterpene lactones from Centaurea species. Planta Med. 1986, 52, 399-401. [CrossRef] 
28. Bohlmann, F.; Singh, P.; King, R.M.; Robinson, H.E. New guaianolides from Pseudostifftia kingii. Phytochemistry 1982, 21, 1171-1172. [CrossRef]

29. Dean, F.M. Naturally occurring coumarins. Chem. Org. Nat. 1952, 9, 225-291.

30. Ma, C.H.; Ke, W.; Sun, Z.L.; Peng, J.Y.; Li, Z.H.; Zhou, X. Large scale isolation and purification of scoparone from Herba Artemisiae scopariae by high speed counter-current chromatography. Chromatographia 2006, 64, 81-87. [CrossRef]

31. Tsukamoto, H.; Hisada, S.; Nishibe, S.; Roux, D.G.; Rourke, J.P. Phenolic glucosides from Olea europea subsp. africana. Phytochemistry 1984, 23, 2839-2841. [CrossRef]

32. Huitink, G.M. Substituted Coumarins as Metallofluorochromic Indicators. Retrospective Theses and Dissertations, Iowa State University, Ames, IA, USA, 1967. Paper 3942.

33. Hewlett, M.J.; Begley, M.J.; Groenewegen, W.A.; Heptinstall, S.; Knight, D.W.; May, J.; Salan, U.; Toplis, D. Sesquiterpene lactones from feverfew, Tanacetum parthenium: Isolation, structural revision, activity against human blood platelet function and implications for migraine therapy. J. Chem. Soc. Perkin Trans. 1996, 16, 1979-1986. [CrossRef]

34. Rybalko, K.S.; Mukametzhanov, M.N.; Sheinchenko, V.I.; Konovalova, O.A. Sesquiterpene lactones of Stizolophus balsamita. Khim. Prir. Soedin. 1976, 12, 467-468.

35. Nowak, G.; Drozdz, B.; Budesinsky, M.; Holub, M. Sesquiterpene lactones. XXXVII. Germacranolides in the genus Stizolophus Cass. Acta Soc. Bot. Pol. 1989, 58, 247-251. [CrossRef]

36. Mukametzhanov, M.N.; Sheinchenko, V.I.; Bankowskii, A.I.; Rybalko, K.S. A sesquiterpene lactone from Stizolophus balsamita. Khim.Prir. Soedin. 1971, 7, 405-406.

37. Tyson, R.L.; Chang, C.J.; Mc Laughlin, J.L.; Aynehchi, Y.; Cassady, J.M. 9-hydroxyparthenolide a novel antitumor sesquiterpene lactone from Anvilea garcini (Burm.) DC. Experientia 1981, 37, 441-442. [CrossRef]

38. Oksuz, S.; Ayyidiz, H. Sesqiuterpene lactones from Stizolophus coronopifolia. Phytochemistry 1986, 25, 535-537. [CrossRef]

39. Imai, S.; Murta, S.; Koreeda, M. Structure of ajugasterone C, a phytoecdysone with an 11-hydroxy-group. J. Chem. Soc. D. 1969, 10, 546-547. [CrossRef]

40. Jizba, J.; Herout, V.; Sorm, F. Polypodine B-A novel ecdysones-like substance from plant material. Tedrahedrom Lett. 1967, 18, 1689-1691. [CrossRef]

41. Hocks, P.; Wiechert, R. 20-hydroxyecdysone isoliert aus insekten. Tetrahedron Lett. 1996, 26, $2089-2993$.

42. Ghosh, P.N.; Fisher, M.C.; Bates, K.A. Diagnosing Emerging Fungal Threats: A One Health Perspective. Front. Genet. 2018, 54. [CrossRef]

43. Harsha, M.V.; Venkatachalam, S.; Pooja, M.; Paranjothy, M. Emerging fungal pathogens: A major threat to human life. Int. J. Pharm. Sci. Res. 2017, 8, 1923-1934.

44. Rosseeuv, D. Achilles foot screening project: Preliminary results of patients screened by dermatologists. J. Eur. Acad. Derm. Venerol. 1999, 12, 6-9. [CrossRef]

45. Badiee, P.; Hashenmizadeh, Z. Opportunistic invasive fungal infections: Diagnosis \& clinical management. Indian J. Med. Res. 2014, 139, 195-204. [PubMed]

46. Segal, E.; Elad, D. Special Issue: Treatments for Fungal Infections. J. Fungi 2018, 4, 135. [CrossRef] [PubMed]

47. Barrero, A.F.; Oltra, J.E.; Alvarez, M.; Raslan, D.S.; Saude, D.A.; Aksira, M. New sources and antifungal activity of sesquiterpene lactone. Fitoterapia 2000, 71, 60-64. [CrossRef]

48. Montagner, C.; de Souze, S.M.; Crospo, C.; Monache, F.D.; Smânia, E.F.; Smânia, A. Antifungal activity of coumarins. Z. Nat. C. J. Biosci. 2008, 63, 21-28. [CrossRef] [PubMed]

49. Iranshahi, M.; Askari, M.; Sahebkar, A.; Adjipavlou-Litina, D. Evaluation of antioxidant, anti-inflammatory and lipoxygenase inhibitory activities of the prenylated coumarin umbelliprenin. Daru J. Pharm. Sci. 2009, 17, 99-103.

50. Kamińska, B. Antifungal Activity of Selected Compounds and Extracts of Some Species Centaurea L. Genus. Ph.D. Thesis, Department of Medicinal and Cosmetic Natural Products, Poznan University of Medical Sciences, Poznań, Poland, 2017.

51. Deen, M.; Christensen, C.E.; Hougaard, A.; Hansen, H.D.; Knudsen, G.M.; Ashina, M. Serotonergic mechanisms in the migraine brain-A systematic review. Cephalalgia 2017, 37, 251-264. [CrossRef] 
52. Bogrdorff, P.; Tangelder, G.J. Migraine: Possible Role of Shear-Induced Platelet Aggregation with Serotonin Release. Headache 2012, 52, 1298-1318.

53. Materazzi, S.; Benemei, S.; Fusi, C.; Gualdani, R.; De Siena, G.; Vastani, N.; Anderson, D.A.; Trevisan, G.; Moncelli, M.R.; Wei, X.; et al. Parthenolide inhibits nociception and neurogenic vasodilatation in the trigeminovascular system by targetting TRPA1 chanel. Pain 2013, 154, 2750-2758. [CrossRef]

54. European Scientific Cooperative on Phytotherapy (ESCOP). ESCOP Monographs: The Scientific Foundation for Herbal Medicinal Products, 2nd ed.; Thieme: New York, NY, USA, 2003; pp. 492-498.

55. Tassorelli, C.; Greco, R.; Morazzoni, P.; Riva, A.; Sandrini, G.; Nappi, G. Parthenolide is the component of Tanacetum parthenium that inhibits nitroglycerin-induced Fos activation: Studies in an animal model of migraine. Cephalalgia 2005, 25, 612-621. [CrossRef]

56. Lesiak, K.; Koprowska, K.; Zalesna, I.; Nejc, D.; Duchler, M.; Czyź, M. Parthenolide, a sesquiterpene lactone from the medical herb feverfew, shows anti-cancer activity against human melanoma cells in vitro. Melanoma Res. 2010, 20, 21-34. [CrossRef] [PubMed]

57. Wyrebska, A.; Gach, K.; Janecka, A. Combined effect of parthenolide and various anti-cancer drugs or anticancer candidate substances on malignant cells in vitro and in vivo. Mini Rev. Med. Chem. 2014, 14, 222-228. [CrossRef] [PubMed]

58. Won, J.K.; Ong, C.N.; Shi, X.; Shen, H.M. Chemopreventive activity of parthenolide against UVB-induced skin cancer and its mechanisms. Carcinogenesis 2004, 25, 1449-1458. [CrossRef] [PubMed]

59. Napierała, M.; Nawrot, J.; Gornowicz-Porowska, J.; Florek, E.; Moroch, A.; Adamski, Z.; Kroma, A.; Miechowicz, I.; Nowak, G. Separation and HPLC characterisation natural steroids and a standardised extract from the Serratula coronata herb with antiseborrheic dermatitis activity. Int. J. Environ. Res. Public Health 2020, 17, 6453. [CrossRef]

60. Heptinstall, S.; Groenwegen, W.A.; Spangenberg, P.; Loesche, W. Extracts Feverfew may inhibit behavior via naturalisation of sulphydryl groups. J. Pharm. Pharm. 1987, 39, 459-465. [CrossRef]

61. Wyganowska-Swiatkowska, M.; Nohawica, M.; Grocholewicz, K.; Nowak, G. Influence of herbal medicines on HMBG1 release, SARS-CoV-2 viral attachment, acute respiratory failure and sepsis. A literature review. Int. J. Mol. Sci. 2020, 21, 4639. [CrossRef]

62. Hadas, E.; Derda, M.; Nawrot, J.; Nowak, G.; Thiem, B. Evaluation of the amoebicidal activities of Centaurea bella, Centaurea daghestanica, Rhaponticum pulchrum and Tanacetum vulgarae against pathogenic Acathamoeba spp. Acta Pol. Pharm. 2017, 74, 1827-1832.

63. Picman, A.K. Biological activities of sesquiterpene lactones. Biochem. Syst. Ecol. 1986, 14, 255-281. [CrossRef]

64. Dinan, L. Phytoecdysteroids biological aspects. Phytochemistry 2001, 57, 325-339. [CrossRef]

65. Clark, G.W.; Pope, S.M.; Jaboori, K.A. Diagnosis and treatment of seborrheic dermatitis. Am. Fam. Physician 2015, 91, 185-190.

66. Dinan, L.; Lafont, R. Effects and applications of arthropod steroid hormones (ecdysteroids) in mammals. J. Endocrinol. 2006, 191, 1-8. [CrossRef] [PubMed]

67. Patel, S.S.; Savjani, J.K. Systematic review of plant steroids as potential anti-inflammatory agents: Current status and future perspectives. J. Phytopharm. 2015, 4, 121-125.

68. Meybeck, A.; Bonté, F. Ecdysteroid-containing liposomes for wound healing and skin regeneration. Chem. Abstr. 1990, 114, 30138.

69. Ali, S.; Khan, F.I.; Mohammad, T.; Lan, D.; Hassan, M.I.; Wang, Y. Identification and Evaluation of Inhibitors of Lipase from Malassezia restricta using Virtual High-Throughput Screening and Molecular Dynamics Studies. Int. J. Mol. Sci. 2019, 20, 884. [CrossRef] [PubMed]

70. Han, P.; Han, J.; Zhang, M. 20-Hydroxyecdysone enhances Immulectin-1ediated immune response against entomogenous fungus in Locusta migratoria. Pest Manag. Sci. 2020, 76, 304-313. [CrossRef]

71. Dermar, M.; Dumas, M.; Bonte, F. Effect of ecdysterone on the differentiation of normal keratinocytes in vitro. Eur. J. Derm. 1994, 4, 558-569.

72. Perez-Bernal, A.; Munoz-Perez, M.A.; Camacho, F. Management of facial hyperpigmentation. Am. J. Clin. Derm. 2007, 6, 195-202.

73. Qian, W.; Liu, W.; Zhu, D. Natural skin-whitening compounds for the treatment of melanogenesis (Review). Exp. Med. 2020, 20, 173-185. [CrossRef]

74. Sarkar, R.; Pooja Arora, P.; Garg, K.V.J. Cosmeceuticals for Hyperpigmentation: What is Available? Cutan. Aesthet. Surg. 2013, 6, 4-11. [CrossRef] 
75. Balkrishnan, R.; Kelly, A.P.; Mc Michael, A.; Torok, H. Improved quality of life with effective treatment of facial melasma: The pigment trial. J. Drugs Derm. 2004, 3, 377-381.

76. Morag, M.; Nawrot, J.; Siatkowski, I.; Adamski, Z.; Fedorowicz, T.; Dawid-Pać, R.; Urbańska, M.; Nowak, G. A double-blind, placebo-controlled randomized trial of Serratulae quinquefoliae folium, a new source of $\beta$-arbutin, in selected skin hyperpigmentations. J. Cosmet. Derm. 2015, 14, 185-190. [CrossRef] [PubMed]

Sample Availability: Samples of the compounds-cebellin L, cebellin A, cebellin B, acroptilin, scoparone, scopoletin, umbelliferone, izospiciformin, stizolin, stizolicin, aiugasterone C, polypodine B, 20-hydroxyecdysone, $\beta$-arbutin are available.

Publisher's Note: MDPI stays neutral with regard to jurisdictional claims in published maps and institutional affiliations.

(C) 2020 by the authors. Licensee MDPI, Basel, Switzerland. This article is an open access article distributed under the terms and conditions of the Creative Commons Attribution (CC BY) license (http://creativecommons.org/licenses/by/4.0/). 